\title{
Policy Implementation in Urban Bangladesh: Role of Intra-organizational Coordination
}

\author{
Pranab Kumar Panday
}

Published online: 19 September 2007

(C) Springer Science + Business Media, LLC 2007

Erratum to: Public Organiz Rev(2007) 7:237-259

DOI 10-1007/s11115-007-0034-3

The original version of this article unfortunately contained a mistake. The content of footnote number 1 was incorrect. The corrected text is given below.

Bangladesh is a South Asian Country became independent on 16th December, 1971 after a bloody war of liberation which lasted for nine months.

The online version of the original article can be found at http://dx.doi.org/10.1007/s11115-007-0034-3.

P. K. Panday $(\bowtie)$

Department of Public and Social Administration, City University of Hong Kong, 83, Tat Chee Avenue, Kowloon Tong, Hong Kong

e-mail: pranabpanday@yahoo.com 